\title{
How the vegetarian diet influences recreational and professional athletes' physical performance: A systematic review
}

\author{
Como a dieta vegetariana influencia o desempenho físico de atletas recreativos e profissionais: Uma \\ revisão sistemática
}

Cómo influye la dieta vegetariana en el rendimiento físico de lo atletas recreativos y profesionales: Una revisión sistemática

\begin{abstract}
Vegetarianism has been getting increasing attention over the years, in society in general and in sport in particular. However, the growth in the number of people following a meatless diet notwithstanding, vegetarianism should be practiced with caution, especially by professional and recreational athletes, considering the possible lack of certain nutrients and decline in their physical performance. Therefore, the present review aimed to determine whether following a vegetarian diet influences recreational and professional athletes' physical and sports performance. A search of the databases Medline/Pubmed, Scopus, Web of Science, and Lilacs gave 343 relevant articles; however, only 15 of these focused on the vegetarian diet and physical performance, in accordance with the inclusion criteria. These studies compared the vegetarian diet with the omnivorous diet, and found that it did not negatively influence physical performance. Moreover, those who followed a vegetarian diet seemed to have a higher volume of maximum oxygen $\left(\dot{\mathrm{VO}}_{2} \mathrm{max}\right)$, which positively influenced their performance. In conclusion, following a plant-based diet does not seem to harm recreational and professional athletes.
\end{abstract}

Keywords: Adults; Vegetarian diet; Physical and sports performance.

\section{Resumo}

O vegetarianismo tem recebido atenção crescente ao longo dos anos, na sociedade em geral e no esporte em particular. Contudo, apesar do crescimento do número de pessoas que seguem uma dieta sem carne, o vegetarianismo deve ser praticado com cautela, principalmente por atletas profissionais e recreativos, considerando a possível falta de alguns nutrientes e declínio no desempenho físico. Portanto, a presente revisão teve como objetivo determinar se seguir uma dieta vegetariana influencia o desempenho físico e esportivo de atletas recreativos e profissionais. Uma busca nas bases de dados Medline / Pubmed, Scopus, Web of Science e Lilacs resultou em 343 artigos relevantes; no entanto, apenas 15 desses enfocavam a dieta vegetariana e desempenho físico, de acordo com os critérios de inclusão. Esses estudos compararam a dieta vegetariana com a dieta onívora e descobriram que ela não influenciava negativamente o desempenho físico. Além disso, quem seguia dieta vegetariana parecia ter maior consumo máximo de oxigênio $\left(\dot{\mathrm{V}}_{2}\right.$ max), o que influenciava positivamente em seu desempenho. Em conclusão, seguir uma dieta baseada em vegetais não parece prejudicar os atletas recreativos e profissionais.

Palavras-chave: Adultos; Dieta vegetariana; Rendimento físico-esportivo.

\section{Resumen}

El vegetarianismo ha recibido una atención cada vez mayor a lo largo de los años, en la sociedad en general y en el deporte en particular. Sin embargo, a pesar del crecimiento en el número de personas que siguen una dieta sin carne, el vegetarianismo debe practicarse con precaución, especialmente por parte de los atletas profesionales y recreativos, considerando la posible falta de ciertos nutrientes y la disminución de su rendimiento físico. Por lo tanto, la presente revisión tuvo como objetivo determinar si seguir una dieta vegetariana influye en el rendimiento físico y deportivo de 
los atletas recreativos y profesionales. Una búsqueda en las bases de datos Medline / Pubmed, Scopus, Web of Science y Lilacs arrojó 343 artículos relevantes; sin embargo, solo 15 de ellos se enfocaron en la dieta vegetariana y el rendimiento físico, de acuerdo con los criterios de inclusión. Estos estudios compararon la dieta vegetariana con la dieta omnívora y encontraron que no influyó negativamente en el rendimiento físico. Además, los que siguieron una dieta vegetariana parecían tener un mayor volumen de oxígeno máximo $\left(\mathrm{VO}_{2}\right.$ máx.), Lo que influyó positivamente en su rendimiento. En conclusión, seguir una dieta a base de plantas no parece perjudicar a los deportistas recreativos y profesionales.

Palabras clave: Adultos; Dieta vegetariana; Rendimiento físico y deportivo.

\section{Introduction}

Vegetarianism has been receiving increasing attention worldwide; as a result, the number of people practicing it has increased over the years. Approximately $22 \%$ of the world's population is vegetarian, while $8 \%$ of elite athletes are vegetarian (Collins et al. 2020).

The Brazilian Vegetarian Society (2017) considers vegetarianism as the dietary regime that excludes all types of meat and may, in some categories, include animal derivatives. However, the vegetarian diet can be classified in different ways, depending on the inclusion or exclusion of certain animal products. In this sense, a vegetarian can be categorized under one of the following four classifications: "ovolactovegetarian"- those who consume eggs and dairy products; "lactovegetarian"those who consume dairy products but not eggs; "ovovegetarian" — those who consume eggs but not dairy products; or "strict vegetarian"- those who do not consume any animal products or ingredients such as gelatin, albumin, milk proteins, some dyes, and thickeners (Slywitch 2012). Moreover, according to the definition provided by the Vegan Society. (n.d.), vegans are also considered strict vegetarians in terms of diet. In addition to diet, veganism is a philosophy of life that tries to exclude all things related to animal exploitation, including food, cosmetics, and clothing.

While there are several reasons motivating individuals to become vegetarians, such as religiosity, sustainability, moral beliefs, and being against different treatment in relation to other species; however, according to Courceiro et al. (2008), health seems to be the most common reason. Some studies have associated the vegetarian diets with a lower risk of cardiovascular and metabolic diseases (Orlich et al. 2013; Kim et al. 2019; Qian et al. 2019). Moreover, a balanced vegetarian diet is associated with a higher intake of complex carbohydrates, fiber, fruits, vegetables, antioxidants, phytochemicals, and a lower intake of saturated fat and cholesterol, when compared with the omnivorous diet (Ada 2003; Rauma \& Mykkanen 2000; Huang et al. 1999). Conversely, the general population still believes that a diet devoid of animal products may be associated with poor performance due to the lack of certain nutrients, such as protein, creatine, vitamin B12, and vitamin ${ }_{\mathrm{D}}$ (Fields et al. 2016; Solis et al. 2017).

According to the American College of Sports Medicine (2016), "the performance of, and recovery from, sporting activities are enhanced by well-chosen nutrition strategies" (p. 543). Therefore, the nutritional aspect must be considered as an important factor for recreational athletes' and professional athletes' physical and sports performance. The American Dietetic Association (2003) argues that vegetarianism and veganism are suitable for different groups of people such as pregnant women, nursing mothers, children, adolescents, adults, and even athletes. However, even in a balanced vegetarian diet, which is considered appropriate for maintaining health throughout one's life cycle (Craig \& Mangels 2009), attention should be paid to nutritional adequacy vis-à-vis physical performance in professional and recreational athletes, as many of their necessary and desirable nutritional needs may remain unmet, leading to a decline in performance.

Considering the increasing adherence to plant-based diets, without meat consumption and with regular physical exercise, this systematic literature review aimed to determine whether following a vegetarian diet influences recreational athletes' and professional athletes' physical and sports performance. 


\section{Methodology}

\section{Eligibility criteria}

The research strategy was defined based on the question "Does following a vegetarian diet influence recreational athletes' and professional athletes' physical and sports performance?" and considered the PICO (Guyatt et al. 2008) (Population; Intervention; Comparison; Outcome) components.

Population: adults or the elderly

Intervention: vegetarian diet

Comparison: not following a vegetarian diet

Outcome: increase or decrease in physical and sports performance

All observational studies that sought to identify the effects if vegetarian diets on physical and sports performance were considered eligible. Publications such as letters to the editor, editorials, literature reviews, meta-analyses, and points of view were excluded.

\section{Search sources and strategies}

The databases searched were Medline/Pubmed, Scopus, Web of Science, and Lilacs by employing independent search strategies. The references of the eligible articles were checked to select studies of interest. The search strategies using keywords, other terms, and Boolean language are described in Table 1, which was conducted in accordance with the guideline described by the Preferred Reporting Items for Systematic Review and Meta-Analysis (PRISMA) (Liberati et al, 2009).

Table 1. Search Strategies in different bases

\begin{tabular}{|c|c|c|c|}
\hline Base & Strategie & $\begin{array}{l}\text { Data of the last } \\
\text { research }\end{array}$ & Result \\
\hline Medline/ Pubmed & $\begin{array}{l}\text { ((Adult[MeSH] OR Adult[TiAb] OR athletes[MeSH] OR athlete*[TiAb] OR } \\
\text { "practicing sports"[TiAb] OR "practicing physical activities"[TiAb]) AND } \\
\text { ("Diet, Vegetarian"[MeSH] OR vegetarian[TiAb] OR vegan[TiAb] OR "energy } \\
\text { restricted diets" [TiAb]) AND ("Athletic Performance"[MeSH] OR "Athletic } \\
\text { Performance "[TiAb] OR "Sports performance"[TiAb] OR "physical } \\
\text { performance"[TiAb] OR OR performance"[TiAb])) }\end{array}$ & $04 / 19 / 2021$ & 76 \\
\hline Scopus & $\begin{array}{l}\text { (TITLE-ABS-KEY (adult* OR athlete* OR "practicing sports" OR "practicing } \\
\text { physical activities") AND TITLE-ABS-KEY ("Diet, Vegetarian" OR vegetarian } \\
\text { OR vegan OR "energy restricted diets") AND TITLE-ABS-KEY ("Athletic } \\
\text { Performance" OR "Sports performance" OR "physical performance" OR } \\
\text { performance)) }\end{array}$ & $04 / 19 / 2021$ & 186 \\
\hline Web of Science & $\begin{array}{l}\text { (Adult* OR athlete* OR "practicing sports" OR "practicing physical activities") } \\
\text { AND TÓPICO: ("Diet, Vegetarian" OR vegetarian OR vegan OR "energy } \\
\text { restricted diets") AND TÓPICO: (“Athletic Performance" OR "Sports } \\
\text { performance" OR "physical performance" OR performance) }\end{array}$ & $04 / 19 / 2021$ & 79 \\
\hline Lilacs & $\begin{array}{l}\text { (atleta OR atletas OR esporte OR esportes OR "atividade física") AND } \\
\text { (vegetariana OR vegetariano OR vegan OR vegetarianas OR vegetarianos OR } \\
\text { veganos OR "dieta com restrição de energia") AND (performance) }\end{array}$ & $04 / 19 / 2021$ & 2 \\
\hline \multicolumn{3}{|l|}{ Total } & 343 \\
\hline
\end{tabular}

Source: Authors.

\section{Risk of bias}

After the articles were selected, duplicate records were removed. Subsequently, the three authors selected the articles independently, starting with the title. The reviewers then analyzed the articles, and disagreements were resolved in accordance 
with all authors. Thereafter, the three authors read the abstracts of the selected articles and independently selected the eligible ones, thus ensuring greater accuracy. Disagreements were resolved by consensus, and the eligible articles were then read in full.

\section{Results}

\section{Article selection}

The initial search yielded 343 articles, of which 15 were selected after following all the steps. Figure 1 shows the entire process.

Figure 1. Flowchart diagram of bibliographic research according to Preferred Reporting Items for Systematic Review and Meta-Analysis (PRISMA) guidelines

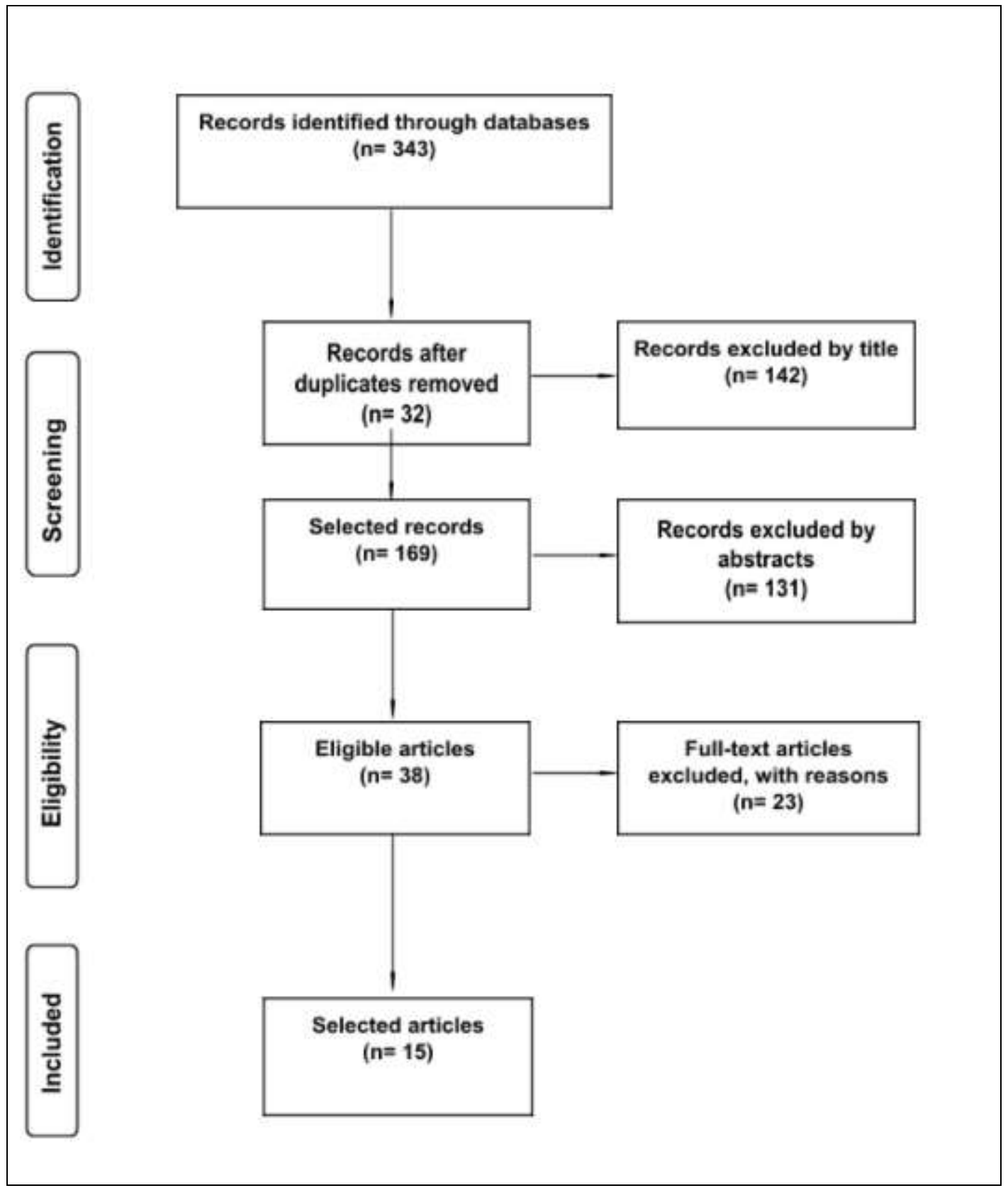

Source: Authors. 


\section{Summary of results}

Among the 15 articles, one (5.6\%) reported that the vegetarian diet negatively influences physical and sports performance, while eight (44.4\%) reported the opposite, and nine (50\%) reported that the diet had no influence on the physical and sports performance (the abovementioned percentages were obtained by considering a total of 18 results in the 15 articles as three articles presented more than one result and, thus, were mentioned in different tables; consequently, these articles had to be counted twice). The studies in which the diet worsened performance, or which showed a negative association between the two are presented in Table 2; those in which the diet improved performance, or which showed a positive association between the two are presented in Table 3; and those in which the diet had no effect on performance, or which showed no association between the two are presented in Table 4 .

Table 2. List of the studies included in the review in which the diet worsened performance, or which showed a negative association between the two (author name, year, aim, sample characteristics, study design and main results)

\begin{tabular}{|l|l|l|l|l|}
\hline \multicolumn{1}{|c|}{ Reference } & \multicolumn{1}{|c|}{ Aim } & \multicolumn{1}{|c|}{ Sample } & \multicolumn{1}{c|}{ Design } & \multicolumn{1}{c|}{ Main Results } \\
\hline $\begin{array}{l}\text { *Hebbelinck et } \\
\text { al. (1999) }\end{array}$ & $\begin{array}{l}\text { To assess average daily dietary } \\
\text { intakes of energy in vegetarian } \\
\text { children, adolescents, and young } \\
\text { adults and included } \\
\text { determination of height and } \\
\text { weight; triceps, suprailiac, and } \\
\text { calf skinfold thicknesses; puberty } \\
\text { ratings; and physical fitness. }\end{array}$ & $\begin{array}{l}\text { Size: } 44 \\
\text { Gender: 31 females and 13 } \\
\text { males } \\
\text { Intervention: 44 } \\
\text { years } \\
\text { Control group: Dutch nutrient } \\
\text { database } \\
\text { Recreational athletes: 44 } \\
\text { Age group: 20 to 22 years } \\
\text { Physical method: Strength; } \\
\text { cardiorespiratory endurance. } \\
\text { Country: United States }\end{array}$ & $\begin{array}{l}\text { Type: Cohort- } \\
\text { study }\end{array}$ & $\begin{array}{l}\text { The results of the physical } \\
\text { fitness tests in the present study } \\
\text { indicate that in the 3 strength } \\
\text { related tests, ie, hand grip } \\
\text { strength (static strength), } \\
\text { standing long jump (explosive } \\
\text { strength), and 30-s sit-up } \\
\text { abdominal strength), the } \\
\text { vegetarian subjects scored at or } \\
\text { below the average level of } \\
\text { performance of their respective } \\
\text { reference age groups. }\end{array}$ \\
\hline
\end{tabular}

Legend: a) Professional athletes are professional competitors, federates. While, recreational athletes do not necessarily participate in competitions. b) * The study by Hebbelinck et al. (1999) identifies contrasting results that can be applied to other tables. There was a negative influence in relation to vegetarian participants in the strength tests, but there was no negative association in relation to the aerobic test for vegetarians in the same study, which can be seen in Table 3. Source: Authors. 
Table 3. List of the studies included in the review in which the diet improved performance, or which showed a positive association between the two (author name, year, aim, sample characteristics, study design and main results)

\begin{tabular}{|c|c|c|c|c|}
\hline Reference & Aim & Sample & Design & Main Results \\
\hline $\begin{array}{l}\text { *Lynch et al. } \\
(2016)\end{array}$ & $\begin{array}{l}\text { To compare elite vegetarian } \\
\text { and omnivore adult endurance } \\
\text { athletes for maximal oxygen } \\
\text { uptake ( }\left(\dot{\mathrm{V}} \mathrm{O}_{2} \text { máx) and strength }\right.\end{array}$ & $\begin{array}{l}\text { Size: } 70 \\
\text { Gender: } 30 \text { females and } 40 \\
\text { males } \\
\text { Intervention: } 27 \text { Vegans for } \geq 2 \\
\text { years } \\
\text { Control group: } 43 \text { omnivores } \\
\text { Professional athletes: } 70 \\
\text { Age group: } 21 \text { to } 58 \text { years } \\
\text { Physical method: } \dot{\mathrm{VO}}_{2} \text { max; } \\
\text { peak torque for leg extensions } \\
\text { Country: Switzerland }\end{array}$ & $\begin{array}{l}\text { Type: Cross- } \\
\text { sectional study }\end{array}$ & $\begin{array}{l}\dot{\mathrm{VO}} \mathrm{O}_{2} \text { max differed for females by } \\
\text { diet group }(53.0 ; \mathrm{sd}=6.9 \text { and } 47.1 \text {; } \\
\mathrm{sd}=8.6 \mathrm{~mL} / \mathrm{kg} / \mathrm{min} \text { for vegetarians } \\
\text { and omnivorous respectively, } \mathrm{p}< \\
0.05) .\end{array}$ \\
\hline $\begin{array}{l}\text { Mujika } \\
(2018)\end{array}$ & $\begin{array}{l}\text { To report on the performance } \\
\text { outcomes and subjective } \\
\text { assessments of long-term low } \\
\text { carbohydrate, high fat (LCHF) } \\
\text { diet in a world-class long- } \\
\text { distance triathlete. }\end{array}$ & $\begin{array}{l}\text { Size: } 1 \\
\text { Gender: male } \\
\text { Intervention: (LCHF) diet for } 32 \\
\text { weeks } \\
\text { Control group: Lacto-ovo } \\
\text { vegetarian } \\
\text { Professional athletes: } 1 \\
\text { Age group: } 39 \text { years } \\
\text { Physical method: Marathon; } \\
\text { ultramarathon } \\
\text { Country: United States }\end{array}$ & $\begin{array}{l}\text { Type: Case } \\
\text { study }\end{array}$ & $\begin{array}{l}\text { The lacto-ovo vegetarian athlete } \\
\text { used a LCHF diet, maintaining his } \\
\text { vegetarian eating pattern, for } 32 \\
\text { weeks. Within those } 32 \text { weeks, his } \\
\text { performance declined. He regained } \\
\text { his usual level of performance } \\
\text { within } 5 \text { weeks of being back on a } \\
\text { high-carbohydrate lacto-ovo } \\
\text { vegetarian diet. }\end{array}$ \\
\hline $\begin{array}{l}\text { Veleba et al. } \\
\text { (2016) }\end{array}$ & $\begin{array}{l}\text { To compare the effects of a } \\
\text { vegetarian and conventional } \\
\text { diet with the same caloric } \\
\text { restriction on physical fitness } \\
\text { and resting energy } \\
\text { expenditure after } 12 \text { weeks of } \\
\text { diet plus aerobic exercise in } \\
\text { patients with type } 2 \text { diabetes } \\
\text { (T2D). }\end{array}$ & $\begin{array}{l}\text { Size: } 74 \\
\text { Gender: } 39 \text { females and } 35 \\
\text { males } \\
\text { Intervention: } 37 \text { Vegetarians } \\
\text { Control group: } 37 \text { Conventional } \\
\text { Hiphocaloric Diet } \\
\text { Recreational athletes: } 74 \\
\text { Ill: } 74 \\
\text { Illness: Type } 2 \text { Diabetes } \\
\text { Age group: - } \\
\text { Physical method: } \text { VO}_{2} \text { máx; } \\
\text { maximal performance (Watt } \\
\text { max) } \\
\text { Country: Switzerland }\end{array}$ & $\begin{array}{l}\text { Type: } \\
\text { Randomized } \\
\text { controlled } \\
\text { study }\end{array}$ & $\begin{array}{l}\text { Maximal oxygen consumption } \\
\left(\dot{\mathrm{V}} \mathrm{O}_{2} \text { máx }\right) \text { increased by } 12 \% \text { in } \\
\text { vegetarian group, whereas no } \\
\text { significant change was observed in } \\
\text { conventional diet. } \\
\text { Watt max increased by } 21 \% \text { in } \\
\text { vegetarians, whereas it did not } \\
\text { change in conventional diet. }\end{array}$ \\
\hline
\end{tabular}




\begin{tabular}{|c|c|c|c|c|}
\hline $\begin{array}{l}\text { *Hebbelinck } \\
\text { et al. (1999) }\end{array}$ & $\begin{array}{l}\text { To assess average daily } \\
\text { dietary intakes of energy in } \\
\text { vegetarian children, } \\
\text { adolescents, and young adults } \\
\text { and included determination of } \\
\text { height and weight; triceps, } \\
\text { suprailiac, and calf skinfold } \\
\text { thicknesses; puberty ratings; } \\
\text { and physical fitness. }\end{array}$ & $\begin{array}{l}\text { Size: } 44 \text { vegetarians } \\
\text { Gender: } 31 \text { females and } 13 \\
\text { males } \\
\text { Intervention: } 44 \\
\text { Lactoovovegetarians for } \geq 3 \\
\text { years } \\
\text { Control group: Dutch nutrient } \\
\text { database } \\
\text { Recreational athletes: } 44 \\
\text { Age group: } 20 \text { to } 22 \text { years } \\
\text { Physical method: Strength and } \\
\text { cardiorespiratory endurance. } \\
\text { Country: United States }\end{array}$ & $\begin{array}{l}\text { Type: Cohort- } \\
\text { study }\end{array}$ & $\begin{array}{l}\text { Both the vegetarian male and } \\
\text { young adults performed better in the } \\
\text { step test than did the reference } \\
\text { group. This latter finding suggests } \\
\text { that the vegetarian subjects had } \\
\text { better cardiorespiratory endurance. }\end{array}$ \\
\hline $\begin{array}{l}\text { Leischik e } \\
\text { Spelsberg } \\
(2014)\end{array}$ & $\begin{array}{l}\text { To present the findings of an } \\
\text { ultra-triathlete living on a raw } \\
\text { vegan diet and having finished } \\
\text { the competitions under these } \\
\text { nutritional conditions. }\end{array}$ & $\begin{array}{l}\text { Size: } 11 \\
\text { Gender: } 11 \text { Females } \\
\text { Intervention: } 1 \text { Raw vegan for } 6 \\
\text { years } \\
\text { Control group: } 10 \text { Mixed diet } \\
\text { Professional athletes: } 11 \\
\text { Age group: } 47 \text { to } 48 \text { years } \\
\text { Physical method: Maximum } \\
\text { ergometric performance; } \mathrm{VO}_{2} \text {; } \\
\% \mathrm{VO}_{2} \text { max; } \mathrm{VO}_{2} \text { at the } \\
\text { ventilatory anaerobic threshold } \\
\text { (VAT); } \mathrm{VO}_{2} \text { at respiratory } \\
\text { compensation point (RCP) } \\
\text { Country: } \mathrm{United} \mathrm{States}^{2}\end{array}$ & $\begin{array}{l}\text { Type: Case } \\
\text { report }\end{array}$ & $\begin{array}{l}\text { In terms of performance } \\
\text { diagnostics, the vegan athlete } \\
\text { showed comparable } \dot{\mathrm{V}} \mathrm{O}_{2} \text { max, } \dot{\mathrm{VO}}_{2} \\
\text { at the ventilatory anaerobic } \\
\text { threshold, and } \% \dot{\mathrm{V}} \mathrm{O}_{2} \text { max at } \\
\text { ventilatory anaerobic threshold } \\
\text { values as compared with the control } \\
\text { group. } \dot{\mathrm{V}} \mathrm{O}_{2} \text { and } \% \dot{\mathrm{V}} \mathrm{O}_{2} \text { max at } \\
\text { respiratory compensation point were } \\
\text { somewhat higher for the vegan } \\
\text { athlete. The maximum ergometric } \\
\text { performance is higher for the vegan } \\
\text { athlete in absolute terms. }\end{array}$ \\
\hline $\begin{array}{l}\text { Gazanni et al. } \\
\text { (2019) }\end{array}$ & $\begin{array}{l}\text { To assess the association } \\
\text { between protein intake and } \\
\text { physical performance in a } \\
\text { general population sample. }\end{array}$ & $\begin{array}{l}\text { Size: } 223 \\
\text { Gender: } 127 \text { Females and } 96 \\
\text { males } \\
\text { Intervention: Linear regression } \\
\text { of 6-min walking test (6MWD) } \\
\text { against nutrient intakes for an } \\
\text { increase of } 10 \text { g/day vegetable } \\
\text { protein } \\
\text { Control group: Linear } \\
\text { regression of 6-min walking test } \\
\text { (6MWD) against nutrient } \\
\text { intakes for an increase of } 10 \\
\text { g/day animal protein } \\
\text { Professional athletes: } 115 \\
\text { Recreational athletes: } 108 \\
\text { Age group: } 45.8 \text { sd = } 9.6 \text { years } \\
\text { Physical method: Global } \\
\text { analisys of the } \\
\text { cardiorespiratory; metabolic } \\
\text { system } \\
\text { Country: Sweden }\end{array}$ & $\begin{array}{l}\text { Type: Case- } \\
\text { control study }\end{array}$ & $\begin{array}{l}\text { As the main outcome measure was } \\
\text { used the } 6 \text {-min walking test and the } \\
\text { distance walked in metres. Their } \\
\text { mean vegetable and animal proteins } \\
\text { intake for gram } / \mathrm{kg} \text { of body } \\
\text { weight/day were, respectively, } 0.4 \\
\text { and } 0.7 \text {. After adjusting for all the } \\
\text { potential confounders, there was a } \\
\text { significant increase of } 20.0 \mathrm{~m} \text { in the } \\
\text { distance walked for an increase in } \\
10 \text { g/day of vegetable proteins and } \\
\text { non-significant variations of }-1.8 \mathrm{~m} \\
\text { for an increase in } 10 \mathrm{~g} / \text { day of } \\
\text { animal proteins and of } 0.5 \text { for an } \\
\text { increase in } 10 \mathrm{~g} / \text { day of total } \\
\text { proteins. The result suggests a } \\
\text { positive role of vegetable proteins } \\
\text { on physical performance. }\end{array}$ \\
\hline
\end{tabular}




\begin{tabular}{|c|c|c|c|c|}
\hline $\begin{array}{l}\text { Król et al. } \\
(2020)\end{array}$ & $\begin{array}{l}\text { To assess the differences in } \\
\text { the athletes' heart morphology } \\
\text { and function and the } \\
\text { correlation of these with } \\
\text { dietary habits. }\end{array}$ & $\begin{array}{l}\text { Size: } 52 \\
\text { Gender: - } \\
\text { Intervention: } 22 \text { Vegans } \\
\text { Control group: } 30 \text { Omnivores } \\
\text { Recreational athletes: } 52 \\
\text { Age group: > } 18 \text { years } \\
\text { Physical method: } \mathrm{VO}_{2} \text { max; } \\
\text { heart functions } \\
\text { Country: Sweden }\end{array}$ & $\begin{array}{l}\text { Type: Case- } \\
\text { control study }\end{array}$ & $\begin{array}{l}\text { Vegans displayed a higher } \dot{\mathrm{V}} \mathrm{O}_{2} \mathrm{max} \\
\mathrm{x}(54.08 \mathrm{vs} .50 .10 \mathrm{~mL} / \mathrm{kg} / \mathrm{min}, \mathrm{p}< \\
0.05) . \\
\text { The vegans presented a more } \\
\text { eccentric form of remodelling with } \\
\text { greater left ventricular end diastolic } \\
\text { diameter (LVEDd, } 2.93 \mathrm{vs} .2 .81 \\
\mathrm{~cm} / \mathrm{m} 2, \mathrm{p}=0.04) \text { and a lower } \\
\text { relative wall thickness (RWT, } 0.39 \\
\text { vs. } 0.42, \mathrm{p}=0.04) \text { and left } \\
\text { ventricular mass (LVM, } 190 \mathrm{vs.} 210 \\
\mathrm{~g}, \mathrm{p}=0.01) \text {. } \\
\text { The results demonstrate that } \\
\text { following a plant-based diet does } \\
\text { not impair amateur athletes' } \\
\text { performance and influences both } \\
\text { morphological and functional heart } \\
\text { remodelling. }\end{array}$ \\
\hline $\begin{array}{l}* \text { Boutros et } \\
\text { al. (2020) }\end{array}$ & $\begin{array}{l}\text { To examine endurance and } \\
\text { muscle strength differences } \\
\text { between vegan and omnivore } \\
\text { participants. }\end{array}$ & $\begin{array}{l}\text { Size: } 56 \\
\text { Gender: Female } \\
\text { Intervention: } 28 \text { Vegans for } \geq 2 \\
\text { years } \\
\text { Control group: } 28 \text { Omnivores } \\
\text { Recreational athletes: } 56 \\
\text { Age group: } 25.6 \text { sd= } 4.1 \text { years } \\
\text { Physical method: } \mathrm{VO}_{2} \text { max; } \\
70 \% \text { of VO2 max; muscle } \\
\text { strength } \\
\text { Country: England }\end{array}$ & $\begin{array}{l}\text { Type: Case- } \\
\text { control study }\end{array}$ & $\begin{array}{l}\text { Vegans had a significantly higher } \\
\text { estimated } \dot{\mathrm{V}} \mathrm{O}_{2} \text { max and submaximal } \\
\text { endurance time to exhaustion } \\
\text { compared with omnivores. }\end{array}$ \\
\hline
\end{tabular}

Legend: a) Professional athletes are professional competitors, federates. While, recreational athletes do not necessarily participate in competitions. b) * The studies identify contrasting results that could be applied to other tables. c) The study by Lynch et al. (2016) demonstrate a difference in the maximum $\dot{\mathrm{V}}_{2}$ variable for women, nevertheless there was no such difference for males in the study. d) Boutros et al. (2020) verify a difference in the variable of maximum $\dot{\mathrm{VO}}_{2}$ and submaximal endurance time to exhaustion, however there were no significant differences in relation to the other variables. The other results of the articles could be seen in Table 4. Source: Authors. 
Table 4. List of the studies included in the review in which the diet had no effect on performance, or which showed no association between the two (author name, year, aim, sample characteristics, study design and main results).

\begin{tabular}{|c|c|c|c|c|}
\hline Reference & Aim & Sample & Design & Main Results \\
\hline $\begin{array}{l}\text { * Lynch et } \\
\text { al. (2016) }\end{array}$ & $\begin{array}{l}\text { To compare elite } \\
\text { vegetarian and } \\
\text { omnivore adult } \\
\text { endurance athletes for } \\
\text { maximal oxygen uptake } \\
\text { (ं் }{ }_{2} \text { máx) and strength. }\end{array}$ & $\begin{array}{l}\text { Size: } 70 \\
\text { Gender: } 30 \text { females and } 40 \text { males } \\
\text { Intervention: } 27 \text { Vegans for } \geq 2 \text { years } \\
\text { Control group: } 43 \text { omnivores } \\
\text { Professional athletes: } 70 \\
\text { Age group: } 21 \text { to } 58 \text { years } \\
\text { Physical method: } \dot{\mathrm{V}}_{2} \text { max; peak torque } \\
\text { for leg extensions } \\
\text { Country: Switzerland }\end{array}$ & $\begin{array}{l}\text { Type: Cross- } \\
\text { sectional study }\end{array}$ & $\begin{array}{l}\mathrm{VO}_{2} \text { max did not differ for males } \\
\text { by diet group. Peak torque did } \\
\text { not differ significantly between } \\
\text { diet groups. }\end{array}$ \\
\hline $\begin{array}{l}\text { Raben et al. } \\
(1992)\end{array}$ & $\begin{array}{l}\text { The effect of a lacto-ovo } \\
\text { vegetarian and a mixed, } \\
\text { meat-rich diet on the } \\
\text { level of serum sex } \\
\text { hormones, } \\
\text { gonadotropins, and } \\
\text { endurance performance. }\end{array}$ & $\begin{array}{l}\text { Size: } 8 \\
\text { Gender: Male } \\
\text { Intervention: Lacto-ovo vegetarian } \\
\text { Control group: Mixed diet } \\
\text { Recreational athletes: } 8 \\
\text { Age group: } 21 \text { to } 28 \text { years } \\
\text { Physical method: - } \\
\text { Country: United States }\end{array}$ & $\begin{array}{l}\text { Type: Cross- } \\
\text { over study }\end{array}$ & $\begin{array}{l}6 \text { weeks on a lacto-ovo } \\
\text { vegetarian diet caused a minor } \\
\text { decrease in total testosterone } \\
\text { and no significant changes in } \\
\text { physical performance in male } \\
\text { endurance athletes compared } \\
\text { with } 6 \text { wk on a mixed, meat rich } \\
\text { diet. }\end{array}$ \\
\hline $\begin{array}{l}\text { Nebl et al. } \\
\text { (2019) }\end{array}$ & $\begin{array}{l}\text { To compare the } \\
\text { exercise capacity of } \\
\text { vegan, lacto-ovo } \\
\text { vegetarian and } \\
\text { omnivorous recreational } \\
\text { runners. }\end{array}$ & $\begin{array}{l}\text { Size: } 76 \\
\text { Gender: } 47 \text { Females and } 29 \text { Males } \\
\text { Intervention: } 24 \text { Vegans; } 26 \text { Lacto-ovo } \\
\text { vegetarians } \\
\text { Control group: } 26 \text { Omnivores } \\
\text { Recreational athletes: } 76 \\
\text { Age group: } 18 \text { to } 35 \text { years } \\
\text { Physical method: Maximum power } \\
\text { output; arterial lactate; maximum lactate } \\
\text { Country: United States }\end{array}$ & $\begin{array}{l}\text { Type: Cross- } \\
\text { sectional study }\end{array}$ & $\begin{array}{l}\text { The groups showed comparable } \\
\text { training habits in terms of } \\
\text { training frequency, time and } \\
\text { running distance. Moreover, } \\
\text { similar maximum power output } \\
\text { was observed in all three groups } \\
\text { and no differences regarding } \\
\text { arterial lactate throughout the } \\
\text { exercise test and maximum } \\
\text { lactate could be observed } \\
\text { between the groups. }\end{array}$ \\
\hline $\begin{array}{l}\text { Burke et al. } \\
\text { (2008) }\end{array}$ & $\begin{array}{l}\text { To compare changes in } \\
\text { muscle insulin-like } \\
\text { growth factor-I (IGF-I) } \\
\text { content resulting from } \\
\text { resistance-exercise } \\
\text { training and creatine } \\
\text { supplementation. }\end{array}$ & $\begin{array}{l}\text { Size: } 42 \\
\text { Gender: } 18 \text { Females and } 24 \text { Males } \\
\text { Type of Diet: } 18 \text { lacto-ovo vegetarians or } \\
\text { vegan for } \geq 3 \text { years and } 24 \text { Mixed diet } \\
\text { Intervention: } 22 \text { Creatine supplementation } \\
\text { Control group: } 20 \text { Isocaloric placebo } \\
\text { Recreational athletes: } 43 \\
\text { Age group: } 31 \text { to } 24 \text { years } \\
\text { Physical method: > } 70 \% \text { 1RM } \\
\text { Country: United States }\end{array}$ & $\begin{array}{l}\text { Type: } \\
\text { Randomized } \\
\text { control study }\end{array}$ & $\begin{array}{l}\text { All participants followed the } \\
\text { same high-volume, heavy-load } \\
\text { resistance-exercise-training } \\
\text { program for } 8 \text { weeks. Creatine } \\
\text { supplementation during } \\
\text { resistance-exercise training } \\
\text { increases intramuscular IGF-I } \\
\text { concentration in healthy men } \\
\text { and women, independent of } \\
\text { habitual dietary routine. }\end{array}$ \\
\hline
\end{tabular}




\begin{tabular}{|c|c|c|c|c|}
\hline $\begin{array}{l}\text { Novakova } \\
\text { et al. (2016) }\end{array}$ & $\begin{array}{l}\text { To assess the plasma } \\
\text { and skeletal muscle } \\
\text { carnitine content and } \\
\text { physical performance of } \\
\text { male vegetarians and } \\
\text { matched omnivores } \\
\text { under basal conditions } \\
\text { and after l-carnitine } \\
\text { supplementation. }\end{array}$ & $\begin{array}{l}\text { Size: } 24 \\
\text { Gender: Male } \\
\text { Intervention: } 16 \text { Vegetarians for } \geq 1.5 \\
\text { years with oral supplementation of } 2 \mathrm{~g} \text { l- } \\
\text { carnitine } \\
\text { Control group: } 8 \text { Omnivores with oral } \\
\text { supplementation of } 2 \mathrm{~g} 1 \text {-carnitine } \\
\text { Recreational athletes: } 24 \\
\text { Age group: } 26 \text { to } 31 \text { years } \\
\text { Physical method: } \dot{\mathrm{VO}}_{2} \text { max; } 75 \% \\
\mathrm{VO}_{2} \text { max } \\
\mathrm{Country}_{\text {: Germany }}\end{array}$ & $\begin{array}{l}\text { Type: Case- } \\
\text { control study }\end{array}$ & $\begin{array}{l}\text { Exercise capacity and maximal } \\
\text { oxygen uptake were not } \\
\text { different between vegetarians } \\
\text { and omnivores. Sub-maximal } \\
\text { exercise (75\% VO2max for } 1 \\
\text { h) revealed no significant } \\
\text { differences between vegetarians } \\
\text { and omnivores. } \\
\text { Supplementation with 1- } \\
\text { carnitine significantly increased } \\
\text { the total plasma carnitine } \\
\text { concentration ( } 24 \% \text { in } \\
\text { omnivores, } 31 \% \text { in vegetarians) } \\
\text { and the muscle carnitine content } \\
\text { in vegetarians ( } 13 \% \text { ). } \\
\text { Vegetarians had maintained } \\
\text { skeletal muscle carnitine stores } \\
\text { despite lower plasma carnitine } \\
\text { concentrations than omnivores. }\end{array}$ \\
\hline $\begin{array}{l}\text { Baguet et } \\
\text { al. (2011) }\end{array}$ & $\begin{array}{l}\text { To investigate the } \\
\text { effects of } 5 \text { weeks sprint } \\
\text { training combined with } \\
\text { a vegetarian or mixed } \\
\text { diet on muscle } \\
\text { carnosine, carnosine } \\
\text { synthase mRNA } \\
\text { expression and muscle } \\
\text { buffering capacity. }\end{array}$ & $\begin{array}{l}\text { Size: } 19 \\
\text { Gender: } 9 \text { Females and } 10 \text { Males } \\
\text { Intervention: } 9 \text { subjects were allocated to } \\
\text { a vegetarian diet } \\
\text { Control group: } 10 \text { subjects were allocted } \\
\text { to a mixed diet } \\
\text { Recreational athletes: } 20 \\
\text { Age group: } 16 \text { to } 30 \text { years } \\
\text { Physical method: sprint training program; } \\
\text { Resistance was set to } 7 \text { and } 8 \% \text { of the } \\
\text { bodyweight for females and males, } \\
\text { respectively } \\
\text { Country: Germany }\end{array}$ & $\begin{array}{l}\text { Type: } \\
\text { Randomized } \\
\text { control study }\end{array}$ & $\begin{array}{l}\text { There was a significant diet } 9 \\
\text { trainings interaction in soleus } \\
\text { carnosine content, which was } \\
\text { non-significantly increased with } \\
\text { mixed diet and non-significantly } \\
\text { decreased with vegetarian diet. } \\
\text { Carnosine content in other } \\
\text { muscles and gastrocnemius } \\
\text { buffer capacity were not } \\
\text { influenced by training. The } \\
\text { performance during the repeated } \\
\text { sprint ability test improved by } \\
\text { training, without difference } \\
\text { between groups. } \\
\text { Both groups were supplemented } \\
\text { with } 1 \text { g/day of creatine } \\
\text { monohydrate for } 5 \text { weeks. }\end{array}$ \\
\hline $\begin{array}{l}\text { Shomrat et } \\
\text { al. (2000) }\end{array}$ & $\begin{array}{l}\text { To determine the effect } \\
\text { of creatine feeding on } \\
\text { maximal exercise } \\
\text { performance in } \\
\text { vegetarians. }\end{array}$ & $\begin{array}{l}\text { Size: } 24 \\
\text { Gender: Male } \\
\text { Intervention: } 7 \text { vegetarians and } 9 \text { meat- } \\
\text { eaters ingesting creatine supplemetation } \\
\text { for } 1 \text { week } \\
\text { Control group: } 8 \text { Meat- eaters ingesting } \\
\text { glucose for } 1 \text { week } \\
\text { Recreational athletes: } 24 \\
\text { Age group: } 25 \text { to } 32 \text { years } \\
\text { Physical method: Peak power output } \\
\text { Country: Germany }\end{array}$ & $\begin{array}{l}\text { Type: Clinical } \\
\text { trial }\end{array}$ & $\begin{array}{l}\text { Vegetarians and meat-eaters } \\
\text { respond to creatine feedings } \\
\text { with similar increases in mean } \\
\text { power output during short-term, } \\
\text { maximal exercise. }\end{array}$ \\
\hline $\begin{array}{l}\text { Davey et al. } \\
(2021)\end{array}$ & $\begin{array}{l}\text { To report the process of } \\
\text { an elite male Gaelic } \\
\text { football player } \\
\text { transitioning from an } \\
\text { omnivorous diet to a } \\
\text { vegan diet at the } \\
\text { beginning of a } \\
\text { competitive season. }\end{array}$ & $\begin{array}{l}\text { Size: } 1 \\
\text { Gender: Male } \\
\text { Intervetion: Vegan diet for } 1 \text { year } \\
\text { Control group: Omnivore } \\
\text { Professional athletes: } 1 \\
\text { Age group: } 25 \text { years }\end{array}$ & $\begin{array}{l}\text { Type: Case } \\
\text { study }\end{array}$ & $\begin{array}{l}\text { All physical analysis indicated } \\
\text { that with adequate knowledge } \\
\text { and education, and appropriate } \\
\text { planning, commitment and } \\
\text { iterative feedback, the athlete } \\
\text { was able to meet nutrition } \\
\text { targets on a vegan diet without } \\
\text { compromising key performance } \\
\text { indicators compared to the }\end{array}$ \\
\hline
\end{tabular}




\begin{tabular}{|l|l|l|l|l|}
\hline & & $\begin{array}{l}\text { Physical method: running performance } \\
\text { during match-play } \\
\text { Country: Switzerland }\end{array}$ & $\begin{array}{l}\text { omnivorous diet of the previous } \\
\text { season. }\end{array}$ \\
\hline $\begin{array}{l}\text { *Boutros et } \\
\text { al. (2020) }\end{array}$ & $\begin{array}{l}\text { To examine endurance } \\
\text { and muscle strength } \\
\text { differences between } \\
\text { vegan and omnivore } \\
\text { participants. }\end{array}$ & $\begin{array}{l}\text { Size: } 56 \\
\text { Gender: Female } \\
\text { Intervention: 28 Vegans for } \geq 2 \text { years } \\
\text { Control group: 28 Omnivores } \\
\text { Recreational athletes: } 56 \\
\text { Age group: 25.6 sd=4.1 years } \\
\text { Physical method: VO } 2 \text { max; 70\% of VO2 } \\
\text { max; muscle strength } \\
\text { Country: England }\end{array}$ & $\begin{array}{l}\text { Type: Case- } \\
\text { control study }\end{array}$ & $\begin{array}{l}\text { Both groups, vegans and } \\
\text { omnivores, were comparable in } \\
\text { terms of strength levels in the } \\
\text { upper and lower body muscles. }\end{array}$ \\
\hline
\end{tabular}

Legend: a) Professional athletes are professional competitors, federates. While, recreational athletes do not necessarily participate in competitions. b) * The studies identify contrasting results that could be applied to other tables. Source: Authors.

\section{Discussion}

Only one study showed that the vegetarian diet had a negative influence on athletes' physical performance. Hebbelinck et al. (1999) initiated the use of strength tests to evaluate performance: a hand grip strength test (static strength), a standing long jump test (explosive strength), and abdominal flexion (abdominal strength) test, and found that the performance of the vegetarian participants was poorer than that of those in the control group, the daily energy intake of the vegetarians was significantly lower than that of the omnivores, which could explain the significant difference observed in the strength test performance of the two groups. Thus, each type of exercise and diet requires a different dietary regime to fulfill the energy requirements necessary for optimum performance. Conversely, Boutros et al. (2020) performed the one repetition maximum (1RM) test for upper and lower limbs to analyze muscle strength in vegetarians and omnivores, and found no significant difference between the two groups. It is worth noting that of the 15 studies reviewed, strength tests had been conducted as an analysis resource in only five articles in the present analyze.

Considering that strength athletes have specific needs when it comes to training and nutrients in their diet, future studies should investigate the association between resistance exercises and the vegetarian diet, thus expanding the literature on the topic, which is currently scarce.

In this review, studies indicating that the vegetarian diet is beneficial for performance had conducted aerobic tests to analyze performance, and in most of these, the participants were endurance athletes. Gazanni et al. (2019) evaluated their participants in the short term through only the diets suggested as part of their investigation; furthermore, Veleba et al. (2016) randomly distributed their study participants into a control group and vegetarian group, including the diets suggested only in the investigation.

According to Nieman (1998), vegetarian diets usually have higher levels of carbohydrates, which can be beneficial for endurance athletes as they enhance the body's glycogen reserves, thereby improving performance. Some studies present in this review that showed a positive correlation between the vegetarian diet without supplementation and with aerobic performance, reported an increase in $\dot{\mathrm{V}}_{2}$ max and vagal cardiac activity, which suggests several benefits for the cardiovascular system of these athletes. Nonetheless, some of these studies possess limitations, such as different levels of physical conditioning and uncontrolled diet. Furthermore, Mujika (2019) observed an improvement in the performance of the athletes under analysis in endurance tests using a vegetarian diet, compared with a low-carbohydrate and high-fat diet, however, some questions remain 
unanswered, as food was the only factor analyzed, and other internal and external variables may have interfered with the athlete's performance.

Only one of the studies reviewed had participants with chronic disease, Veleba et al. (2016) enrolled only diabetics, and after following the vegetarian diet along with aerobic exercise, they showed lower visceral fat levels, which may suggest a decrease in muscle fat, indicating a positive association with physical conditioning; the authors also reported a correlation between lower intracellular fat rates in vegetarians and increased insulin sensitivity, and an increase in metabolic flexibility was also observed, indicating a possible correlation between metabolic flexibility and $\mathrm{V}_{2}$ max. According to Olfert and Wattick (2018), diets devoid of animal products, prioritizing whole grains, fruits, vegetables, legumes, and nuts, and low in saturated and trans-fat, which can be characterized as vegetarian diets, are associated with a lower risk of metabolic diseases such as diabetes, and provide physical benefits to patients.

Other studies showed that the vegetarian diet had no influence on performance. In most, the common analysis resource used was the blood test associated with performance tests; variables such as skeletal muscle carnitine content and creatine supplementation were analyzed. Furthermore, the study by Baguet et al. (2011) included omnivorous participants who only after a five-week intervention were able to follow a diet devoid of animal products.

Some of the studies in which the vegetarian diet did not influence physical and sports performance investigated the respective influences of creatine and carnosine on anaerobic activities. According to Barr et al. (2004), creatine is found mainly in poultry, fish, and meat, and is synthesized endogenously; its highest concentration is in the muscle, mainly in the form of phosphocreatine. During exercise, phosphocreatine breaks down to generate energy to resynthesize adenosine triphosphate (ATP). Thus, a high concentration of creatine can prolong the exercise's supra-maximal intensity or shorten the recovery time.

Subsequently, Burke et al. (2008) showed that omnivores have higher levels of creatine. However, vegetarians, because they have lower levels of it, seem to be more receptive to the supplementation of this amino acid and absorb it more, having similar adaptations, and without any impact on athletes who wish to follow this type of a plant-based diet. Shomrat et al. (2000) too conducted a study with creatine supplementation among vegetarians and omnivores, comparing peak and average potency during the Wingate test, found lower creatine levels in vegetarians; however, potency during the test was not significantly affected after supplementation, both groups increased their average potency, but only omnivores increased their peak potency. In contrast to the studies analyzed in the present review, Barr et al. (2004) showed a significantly higher increase in total muscle creatine, lean mass, and better performance in knee flexion and extension among vegetarians after supplementation, suggesting that vegetarian athletes who supplement creatine and participate in sports requiring the ATP/phosphocreatine system may show better results than omnivores.

Almannai et al. (2019) reported that one of the fundamental functions of carnitine is to produce cellular energy. It is primarily found in animal protein and dairy products, which is favorable to omnivores, who absorb it in greater amounts through food. Vegetarians, on the other hand, obtain carnitine mainly through endogenous synthesis.

Novakova et al. (2016) compared body carnitine reserves and physical performance in people following diets with and without animal protein. Although vegetarians had lower plasma carnitine levels, carnitine reserves in skeletal muscle were similar between the two groups. Furthermore, although L-carnitine supplementation led to a slight increase in muscle carnitine, skeletal muscle function and energy metabolism were not affected; thus, performance results did not differ between the groups.

\section{Conclusion}

In conclusion, the present review indicates that there is no consensus on the topic in the literature. However, it should be noted that only one study, which used strength tests to analyze performance, showed that the vegetarian diet worsened 
Research, Society and Development, v. 10, n. 9, e26910917952, 2021

(CC BY 4.0) | ISSN 2525-3409 | DOI: http://dx.doi.org/10.33448/rsd-v10i9.17952

physical and sports performance. To date, few studies have investigated vegetarian diets using strength tests. Moreover, a significant number of those reviewed found that the vegetarian diet had a positive influence on performance, noting a possible improvement in the cardiorespiratory system of the participants engaging in aerobic activities; while others showed that a diet devoid of animal products did not influence recreational and professional athletes' performance many of the variables analyzed had even values, and in the variables in which a difference was observed, such as creatine levels, supplementation was found to reduce such deficiencies.

For future researchers and works, it would be interesting to analyze larger samples of groups considered vegetarian and greater attention to physical methods, such as $\mathrm{V}_{2}$ max and muscle strength is encouraged. In addition, a better leveling of participants in terms of physical conditioning and dietary monitoring will be beneficial.

\section{References}

American Dietetic Association. (2003). Position of the American Dietetic Association of Canada: vegetarian diets. J Am Diet Assoc, 103, 748-65.

Almannai, M., Alfadhel, M., \& El-Hattab, A. W. (2019). Carnitine inborn errors of metabolism. Molecules, $24(18), 3251$.

Baguet, A., Everaert, I., De Naeyer, H., Reyngoudt, H., Stegen, S., Beeckman, S., \& Derave, W. (2011). Effects of sprint training combined with vegetarian or mixed diet on muscle carnosine content and buffering capacity. European journal of applied physiology, 111(10), 2571-2580.

Barr, S. I., \& Rideout, C. A. (2004). Nutritional considerations for vegetarian athletes. Nutrition, 20(7-8), 696-703.

Boutros, G. H., Landry-Duval, M. A., Garzon, M., \& Karelis, A. D. (2020). Is a vegan diet detrimental to endurance and muscle strength?. European journal of clinical nutrition, 74(11), 1550-1555.

Burke, D. G., Candow, D. G., Chilibeck, P. D., MacNeil, L. G., Roy, B. D., Tarnopolsky, M. A., \& Ziegenfuss, T. (2008). Effect of creatine supplementation and resistance-exercise training on muscle insulin-like growth factor in young adults. International journal of sport nutrition and exercise metabolism, 18(4), 389-398.

Collins, J., Maughan, R. J., Gleeson, M., Bilsborough, J., Jeukendrup, A., Morton, J. P., \& McCall, A. (2021). UEFA expert group statement on nutrition in elite football. Current evidence to inform practical recommendations and guide future research. British journal of sports medicine, 55(8), 416-416.

Couceiro, P., Slywitch, E., Lenz, F. (2008). Padrão Alimentar da dieta Vegetariana. Einstein, 6(3):365-73

Davey, D., Malone, S., \& Egan, B. (2021). Case Study: Transition to a Vegan Diet in an Elite Male Gaelic Football Player. Sports, 9(1), 6.

Definition of veganism. (n.d.). Retrieved Deember 14, 2020, from The Vegan Society: Definition of veganism | The Vegan Society.

Fields, H., Ruddy, B., Wallace, M. R., Shah, A., Millstine, D., \& Marks, L. (2016). How to monitor and advise vegans to ensure adequate nutrient intake. The Journal of the American Osteopathic Association, 116(2), 96-99

Gazzani, D., Zamboni, F., Spelta, F., Ferrari, P., Mattioli, V., Cazzoletti, L., \& Ferrari, M. (2019). Vegetable but not animal protein intake is associated to a better physical performance: A study on a general population sample of adults. Food \& nutrition research, 63.

Guyatt, G., Rennie, D., Meade, M., \& Cook, D. (Eds.). (2002). Users' guides to the medical literature: a manual for evidence-based clinical practice (Vol. 706). Chicago: AMA press.

Hebbelinck, M., Clarys, P., \& De Malsche, A. (1999). Growth, development, and physical fitness of Flemish vegetarian children, adolescents, and young adults. The American journal of clinical nutrition, 70(3), 579s-585s.

Huang, Y. C., Lin, W. J., Cheng, C. H., \& Su, K. H. (1999). Nutrient intakes and iron status of healthy young vegetarians and nonvegetarians. Nutrition Research, 19(5), 663-674.

Kim, H., Caulfield, L. E., Garcia-Larsen, V., Steffen, L. M., Coresh, J., \& Rebholz, C. M. (2019). Plant-Based diets are associated with a lower risk of incident cardiovascular disease, cardiovascular disease mortality, and All-Cause mortality in a general population of Middle-Aged adults. Journal of the American Heart Association, 8(16), e012865.

Król, W., Price, S., Śliż, D., Parol, D., Konopka, M., Mamcarz, A., ... \& Braksator, W. (2020). A Vegan Athlete’s Heart-Is It Different? Morphology and Function in Echocardiography. Diagnostics, 10(7), 477.

Leischik, R., \& Spelsberg, N. (2014). Vegan triple-ironman (raw vegetables/fruits). Case reports in cardiology, 2014.

Liberati, A., Altman, D. G., Tetzlaff, J., Mulrow, C., Gøtzsche, P. C., Ioannidis, J. P., ... \& Moher, D. (2009). The PRISMA statement for reporting systematic reviews and meta-analyses of studies that evaluate health care interventions: explanation and elaboration. Journal of clinical epidemiology, 62(10), e1-e34.

Lynch, H. M., Wharton, C. M., \& Johnston, C. S. (2016). Cardiorespiratory fitness and peak torque differences between vegetarian and omnivore endurance athletes: a cross-sectional study. Nutrients, 8(11), 726. 
Research, Society and Development, v. 10, n. 9, e26910917952, 2021

(CC BY 4.0) | ISSN 2525-3409 | DOI: http://dx.doi.org/10.33448/rsd-v10i9.17952

Mujika, I. (2019). Case study: long-term low-carbohydrate, high-fat diet impairs performance and subjective well-being in a world-class vegetarian longdistance triathlete. International journal of sport nutrition and exercise metabolism, 29(3), 339-344.

Nebl, J., Haufe, S., Eigendorf, J., Wasserfurth, P., Tegtbur, U., \& Hahn, A. (2019). Exercise capacity of vegan, lacto-ovo-vegetarian and omnivorous recreational runners. Journal of the International Society of Sports Nutrition, 16(1), 1-8.

Nieman, D. C. (1998). Exercise and resistance to infection. Canadian journal of physiology and pharmacology, 76(5), 573-580.

Novakova, K., Kummer, O., Bouitbir, J., Stoffel, S. D., Hoerler-Koerner, U., Bodmer, M., ... \& Krähenbühl, S. (2016). Effect of 1-carnitine supplementation on the body carnitine pool, skeletal muscle energy metabolism and physical performance in male vegetarians. European journal of nutrition, 55(1), 207-217.

Orlich, M. J., Singh, P. N., Sabaté, J., Jaceldo-Siegl, K., Fan, J., Knutsen, S., ... \& Fraser, G. E. (2013). Vegetarian dietary patterns and mortality in Adventist Health Study 2. JAMA internal medicine, 173(13), 1230-1238.

Olfert, M. D., \& Wattick, R. A. (2018). Vegetarian diets and the risk of diabetes. Current diabetes reports, 18(11), 1-6.

Qian, F., Liu, G., Hu, F. B., Bhupathiraju, S. N., \& Sun, Q. (2019). Association between plant-based dietary patterns and risk of type 2 diabetes: a systematic review and meta-analysis. JAMA internal medicine, 179(10), 1335-1344.

Raben, A. N. N. E., Kiens, B. E. N. T. E., Richter, E. A., Rasmussen, L. B., Svenstrup, B. I. R. G. I. T., Micic, S. N. E. Z. A. N. A., \& Bennett, P. O. U. L. (1992). Serum sex hormones and endurance performance after a lacto-ovo vegetarian and a mixed diet. Medicine and science in sports and exercise, 24(11), $1290-1297$

Rauma, A. L., \& Mykkänen, H. (2000). Antioxidant status in vegetarians versus omnivores. Nutrition, 16(2), 111-119.

Slywitch, E. (2012). Nutritional Guide for Adult Vegetarian Diets. Medicine and Nutrition Department. Brazilian Vegetarian Society. Solis, M. Y., Artioli, G. G., Otaduy, M. C. G., Leite, C. D. C., Arruda, W., Veiga, R. R., \& Gualano, B. (2017). Effect of age, diet, and tissue type on PCr response to creatine supplementation. Journal of Applied Physiology, 123(2), 407-414.

Shomrat, A., Weinstein, Y., \& Katz, A. (2000). Effect of creatine feeding on maximal exercise performance in vegetarians. European journal of applied physiology, 82(4), 321-325.

Thomas, D. T., Erdman, K. A., \& Burke, L. M. (2016). American college of sports medicine joint position statement. nutrition and athletic performance. Medicine and science in sports and exercise, 48(3), 543-568.

Vegetarianismo. (n.d.). Retrieved December 15, 2020, from Brazilian Vegetarian Society: O que é (svb.org.br)

Veleba, J., Matoulek, M., Hill, M., Pelikanova, T., \& Kahleova, H. (2016). “A vegetarian vs. conventional hypocaloric diet: The effect on physical fitness in response to aerobic exercise in patients with type 2 diabetes.” A parallel randomized study. Nutrients, 8(11), 671.

Winston, J. C. (2009). Health effects of vegan diets. Am J Clin Nutr, 89, 1627S-1633S. 